\title{
CULTIVATING STUDENTS' ENVIRONMENTAL AWARENESS BY CREATING BOTTLE GARDEN IN SCHOOL, A QUALITATIVE STUDY
}

\author{
Risya Pramana Situmorang ${ }^{1 *}$ and Sari Dewi Tarigan ${ }^{2}$ \\ ${ }^{1}$ Department of Biology Education, Faculty of Biology, Satya Wacana Christian University, Salatiga, \\ Central Java, Indonesia \\ ${ }^{2}$ Christian Junior High School 2 of Salatiga, Central Java, Indonesia \\ *Corresponding e-mail: pramana.risya@staff.uksw.edu
}

\begin{abstract}
Environmental awareness has becoming a critical value to be integrated among youth. This research aimed to analyze the implementation of students' environmental awareness of Christian Junior High School 2 in Salatiga by creating bottle garden in school. This research was descriptive qualitative which was conducted in the second semester of academic year 2017/2018 and involved 47 students. The data collection techniques used were questionnaire and observation. The implementation of environmental awareness was measured based on the New Ecological Paradigm theory with five main indicators, namely: 1) anti-exemptionalism, 2) anti-anthropocentrism, 3) limits to growth, 4) balance of nature, and 5) eco-crisis. The results showed that by learning through bottle garden activities, students have reached a good understanding of eco-crisis, anti-exemptialism, balance of nature, anti-anthropocentrism, and limit of growth in which the value were 3.35 ; 3.11; 3.2; 3.19; and 3.14 respectively $(3.21 \leq$ score $<3.73)$. This means that the students have possessed a 'good' level of environmental awareness.
\end{abstract}

Keywords: Bottle garden, environmental awareness, gardening, students' environmental awareness

(C) 2018 Department of Biology Education, FTTE, University of Muhammadiyah Malang, Indonesia

\section{INTRODUCTION}

Human activities in the environment give impacts to the environment itself. Their awareness plays an important role in keeping nature balanced and sustainable (Nazarenko \& Kolesnik, 2018). Conversely, as the environment is getting lower quality, caused by large-scale exploitation occurred, it will influence the environmental ecological structure as well. Thus, the usage of natural products certainly needs to be thought out wisely so there will be no more severe environmental damage. It has been common opinion among people that the considerations of excessive use of the environment is a natural thing as the demand for their needs. Yet, an intentional action in damaging the natural environment or its individual component led to destruction or irreversible damage to natural features or ecosystems of two and more entities (Grebennikov, Sangadzhiev, \& Elena, 2016). This condition is an illustration of the low public awareness in preserving the environment. Another problem which often found is the human habit of throwing garbage carelessly. The waste disposal habit can be traced to values, culture and indigenous knowledge inculcated (Daniel \& Ibok, 2013). Furthermore, these various issues, in turn, will make our environmental damage are becoming worse.

Environmental education in schools plays a crucial role in developing the character of caring in community. As a formal education forum, school function is broadening students' knowledge as well as culturing the environmental awareness, as a worth assets, among young people. Teaching and learning in school is regarded to be able to facilitate students to develop their thinking ability and to improve their attitude for protecting the environment (Farida, Hadiansah, Mahmud, \& Munandar, 2017). These functions, consequently, enable the students to understand the importance of protecting the environment (Ramsey \& Rickson, 1976). On the other hands, the school is also responsible for helping students to study human interactions and their behavior on the earth. 
The environmental education is expected to be able to accommodate and nurture students' environmental awareness. The students who are possessed this awareness will stimulate themselves as well as their friends to maintain their surrounding. As the results, the school environment will be healthier and more comfortable to study which elevates students' motivation, achievement, and creativity. However, in fact, the implementations of this environmental education concepts have not meet satisfactory results. This is presumed as the impact of psycho-emotional and culture experiences which become factors which reflect personal attitudes in solving various problems and cause negative reaction to environment (Nazarenko \& Kolesnik, 2018).

Many environmental problems have occurred so far. Serious efforts are needed to conserve the environment including empowering the environmental awareness for students through learning activities. The importance of inculcating character through education in schools is one potential endeavor that can be conducted (Uno \& Nurdin, 2011) as considerable as the integration these concepts into school curricula, particularly, in science subjects. Environmental restructuring effort has been mentioned in the Undang-Undang RI No. 32 which focuses on embedding the school environmental awareness in the form of activities to maintain cleanliness and preservation of living things in school environment. Yusuf (2012) asserted that people development cannot be separated from the experience gained since their childhood. Therefore, people who have good experiences with environmental sustainability will invest positive impact on environmental developments.

Regarding character building, not only do the characters are oriented through classroom materials delivering activities in term of reading and writing the concepts, but a good learning model must be implemented. Thus, students can learn and reflect, or witness the experiences in doing certain actions which trigger their inner urge. Producing environmentally-conciousstudents who actively participate to protect their environment is also, basically, means educates them to have good moral values (Setyowati, 2015). For example, students who have been nurtured to throw their garbage in the trash and like to plant crops are usually those who have discipline, caring, and responsible.
School environment can be utilized as learning media about nature. By conducting the learning process outside the classroom, the boringness witnessed by students can be avoided. This also led the learners to gain the both knowledge and practical experiences to protect the environment in the real conditions contextually. Therefore, a good design of learning activities outside the classroom by teachers is compulsory. However, the problem faced in Christian Junior High School 2 is that the land and plants owned by school in which the students can utilize them as their learning media to learn about ecosystem are limited. This constraint has contributed the low level of students' environmental knowledge. The results of interview with ten students of class VII showed that the students tended to lack understanding of the role of humans in environmental preservation.

Instilling environmental awareness can be done by habituating the students with hands-on environmental activities. One of the activities is to create a garden in the school by utilizing used goods as a planting container. This activity is named as bottle garden activities. Through these activities, not only do the students learn about environmental maintenance and sustainability, but also they achieve more information about the benefits possibly gained from certain plants such as medicinal plants. Bottle garden learning is a gardening activity using plastic bottles as a planting medium so that it can be used as a ecosystem miniature of plants. Learning through bottle garden activities is potential to instill environmental awareness.

The activities involved in the bottle garden learning will stimulate students to think and proceed the information obtained based on the knowledge they find themselves. Meanwhile, teacher facilitates each student as well as evaluates teaching and learning processes implemented. Practically, teacher can ask students to explain about the proper way they did to plant medicinal plant. Besides that, students can also be assessed by exploring their knowledge about some species they planted whether it is related to the right way in taking care the plants or even the advantages possibly gained from them. In addition, bottle garden activities will cultivate responsible and discipline characters in students by caring the plants. Character education which instills within students about right and wrong concepts enables the learners to experience good values 
as worth as implement the values they reached in their daily life (Aqib, 2011; Daryanto \& Darmiatun, 2013).

Bottle garden activities conducted at Christian Junior High School 2 in Salatiga have been expected to instill the environmental awareness among students with activities related to planting and taking care for medicinal plants. Rahmat (2009) explained that students' concern for environmental sustainability can be increased through environmental education organized by the school. Embedding the environmental awareness for junior high school students is one of the factors that support the bottle garden creation program at Christian Junior High School 2 in Salatiga. The active role of students in preserving the environment is expected to encourage students to maintain the school environment through the insight of their environment in which the evaluation processes are crucial to be conducted. Therefore, this research aimed to analyze the implementation of students' environmental awareness of Christian Junior High School 2 in Salatiga by creating bottle garden in school.

\section{METHOD}

This research was conducted at Christian Junior High School 2 in Salatiga. The implementation time was in the second semester of 2017/2018 academic year. This research was qualitative descriptive which addressed the implementation of environmental awareness through bottle garden activities which included planning and implementation activities in learning processes. The main instrument of this study was researchers who taken direct measurements of students' environmental awareness. Students and teachers acted as informants so that they could strengthen information obtained by researchers during the learning process. The research subjects were 47 students from Christian Junior High School 2 in Salatiga. Data collection techniques used were through non-test with questionnaire and observation instruments. Measuring the character of students' environmental awareness was done as the bottle garden activity taken place and after the activation process was completed.

The implementation of environmental awareness was based on the New Ecological Paradigm theory with five main indicators, namely: 1) Anti-exceptionalism, 2) anti- anthropocentrism, 3) limit to growth, 4) balance of nature, 5) eco-crisis (Atav, Altunoğlu, \& Sönmez, 2015).

The operational method of the environmental activity consist of three main activities, include: 1) apparent personal attitudes towards participation in environmental activity desire to give environmental awareness based on activity and improve level of environmental knowledge (cognitive component), 2) scientific and practical conferences on environment (students were asked to bring used bottles from their homes; during the activity, students were asked to design several used bottles as a planting medium, students fill compost soil into used bottles that have been designed, and planted medicinal plants), and 3) the teacher reminded them to recognize the types and the uses of these plants, all students together put plants in the place provided. They also were also reminded to treat plants to watering and fertilizing the plants. The teacher introduced the environment through many theoretical explanatory activities in two meetings. Teacher also gave pictures as examples of activities as well as demonstration, so that students understand to recycle materials for planting media.

Table 1. The range of interval value of student enviromental awareness

\begin{tabular}{cc}
\hline Category & Range \\
\hline Very good & score $>3.73$ \\
Good & $3.21>$ score $\geq 3.73$ \\
Moderate & $2.67>$ score $\geq 3.21$ \\
Low & score $<2.67$ \\
\hline
\end{tabular}

This research used two instruments i.e. observation sheet to observe students' activities. Questionnaire (19 items) to asess students' response during learning in term of measuring students' environmetal awareness.

The data obtained from the questionnaire response then be analyzed statistically by using One Way ANOV Awhich aided by utilizing SPSS software version 20.0 for windows. Meanwhile, the data obtained through observation was analyzed descriptively.

\section{RESULTS AND DISCUSSION}

The implementation of learning through bottle garden activities is a learning program for science subjects in environmental materials. The activity of bottle garden is contextual 
learning by integrating environmental awareness in students. Daryanto and Darmiatun (2013) explained that contextual learning is highly suitable to be used to instill character in children. Bottle garden activity is done by linking the knowledge possessed by students and applying it in their daily life. Thus the teacher can teach students the science materials in real situations. The implementation of environmental awareness through bottle garden activities in science learning showed variety preference results.

The student activities included: design several used bottles as a planting medium, students filled compost soil into used bottles that had been designed, students filled in medicinal plants, and the teacher reminded them to recognize the types and uses of these plants; meanwhile, the all students put their plants in the place provided together. Moreover, the teacher reminded students to treat the plants they cultivated by watering them as well as giving a proper amount of fertilizer. The most memorable activity was to form a bottle designed and filled the plants that were liked by students.

By referring to Figure 1, it can be seen that the highest achievement of the all indicators of contextual learning was eco-crisis in which the score was 3.43. This data suggests that the students' awarness should be improved and encouraged by eco-crisis. Providing both awarness and responsibility is necessary. This means that the eco-crisis is one of the most crucial factors that influence students' character in junior high school VII grade. While the lowest score was on the natural balance indicator with a score of 3.02 (moderate category).

Homogenity test results of observation sheet data showed homogeneous, it was seen that the value of $\mathrm{F}=0.289$ is significant $(\mathrm{p}<0.05)$. Based on hypothesis test results, it can be concluded that there was significant difference of questionnaire $(\mathrm{F}=4.633 ; \mathrm{p}<0.05)$. Thus, creating bottle garden activity based on environmental activity able to improve the environmental activity in the experimental class.

Moreover, there was also significant influence of the use of creating bottle garden based on activities and experiences in implementating of environmental awareness. The bottle garden activity can train students' responsibility better to aware and care the environment. Such attitude in biological science can be interpreted as environmental awareness, because bottle garden activity educate the students' attitude as well as ease them to understand the environmental concepts and apply them properly.

Furthermore, the implementation of learning through bottle garden activities carried out in natural science subjects in Salatiga city has been classified as good (value interval: $3.21 \leq$ score $<3.73$ ). The achievement of environmental awareness is served in Figure 2. The highest number of students were classified as good (25 students), meanwhile 16 students were categorized as moderate in term of their environmental awareness achievement. In contrast, there were the same number of students who were classified into very good and low as many as 3 students for each category.

The enthusiasm of students to participate in learning about the environment influences the character integration processes. Thus, science teacher must conduct an intensive monitoring to the VII graders through their activities in bottle garden activities. This aimed to ensure that the activities are sustainably done as well as character integration within students.

Aspects of eco-crisis in bottle garden activity by using new ecological paradigm of students are in good level (Figure 1). This indicates that students already have an interest in following science learning. Students were active and involved in science learning. The students' interest in environmental learning being an important capital to increase their attitude in environment. Student realize that changes occurred in their environment whether it is in species or population level can destabilize them to survive.

The lowest score of environmental awareness is in the balance of nature aspects (Figure 1). Many students have difficulty in identifying the relationship between re-establish and biological equilibrium. Most of students assumed that equilibrium just protect a species as part of its intention.

Based on the results of the questionnaire, anti-anthropocentrism aspects is adequate with a score of 3.19 (Table 1). Students support the opinion which stated that human have responsibility to develop the resources wisely. The students' arguments that the nature preservation must be considerated is termed as anthropocentric.

The integration of students' environmental awareness character at Christian Junior High 
Situmorang \& Tarigan /JPBI (Jurnal Pendidikan Biologi Indonesia) / 4 (3) (2018) pp. 263-270

School 2 in Salatiga can be seen through the activities of bottle garden which then be embedded in students. The observation results showed that students seemed enthusiastic and active to participate in the classroom and outside activities. They were enthusiastic as involved in determining the design of used bottles to be re-used as a planting medium. Furthermore, several groups of students also stated that the role of humans in the environment can be done by conservation. The concept of student thinking to protect the environment is increasingly strengthened through activities and learning experiences.

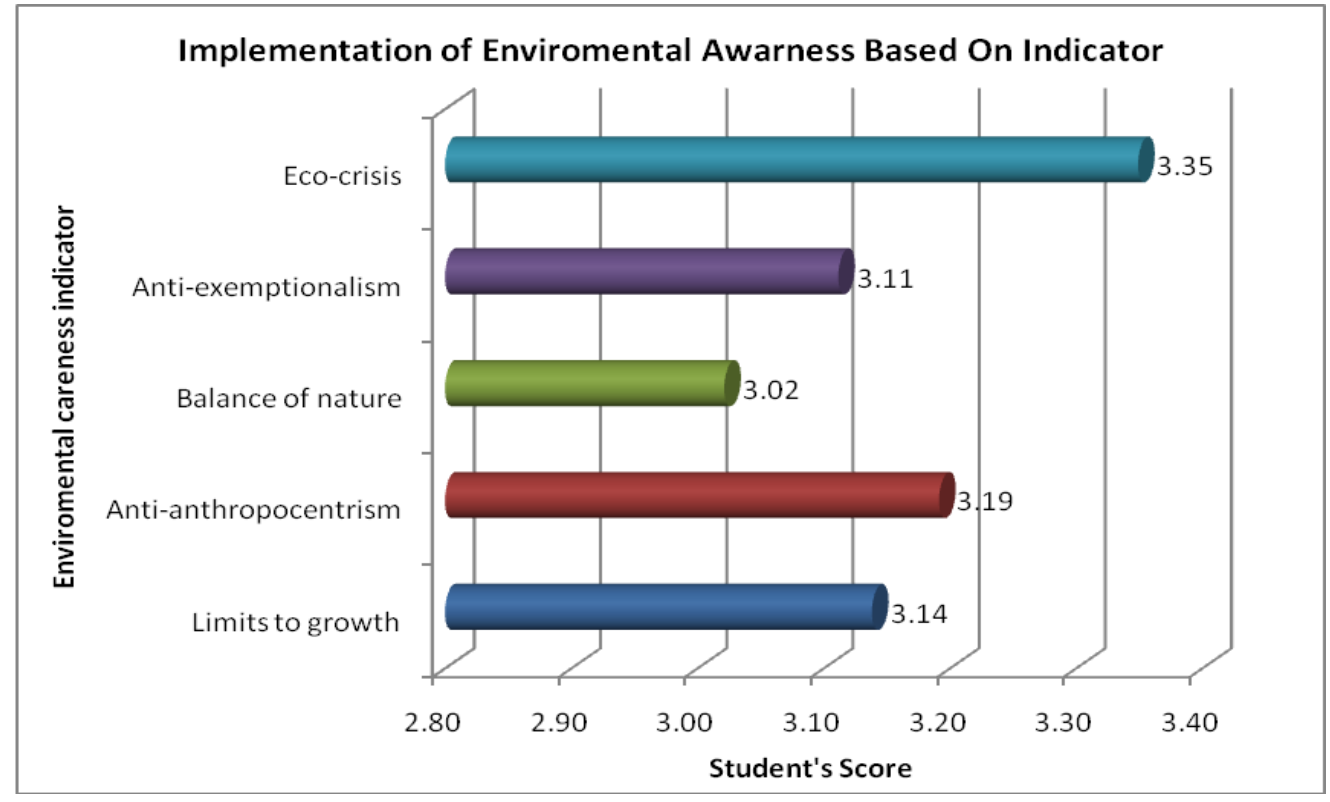

Figure 1. Implementation of environmental awareness



Figure 2. Achievement of environmental awareness

Consequently, ttudents were active in asking questions about the role of humans in the environment. Students' understanding was also realized through the habit of maintaining plants that have been embedded by themselves through bottle garden activities. The students' awareness of caring their environment has begun to develop by caring for the plants every day. Not only do the students watering and fertilizing but they even routinely clean the 
fallen leaves around the area of the bottle garden. This good attitude was fallowed by the other positive behaviours such as throwing trash in the right place, this has been the real evidence that students have possessed responsibility to the environment by maintaining environmental sustainability in schools. In the other word, changing the educational experiences of student by moving beyond the classroom walls can diversify the array of learning opportunities, responsibility and connect school lessons with daily life and real problems about environment (Sata, Wongpho, \& Chankong, 2015).

Student interview data showed that students realize that nature conservation depends on human attitudes and actions. This shows that students have begun to understand the anti-anthropocentrism aspect. Although based on the results of the questionnaire the anti-anthropocentric aspect is in the sufficient category (Figure 1). This is also the same case with students' responses about limit to growth indicators (Figure 1). In general, students already have a positive response in seeing that it is necessary to limit human activities to minimize the exploitation of nature. In general, students see that the understanding to protect the environment comes from family education.

However, students' understanding of antiexceptionalism indicator and natural balance is still moderate (Figure 1). This result implies that humans should be in the laws of nature. While the perception built by students regarding the balance of nature is still limited to the role of nature that is so strong against the activity. Students have not thought about human activities will be able to change nature and cause great harm to humans, for example, natural disasters. In line with study, Thomas (2018) stated that environmental based activities can be used to teach environmental values carried out by schools and learning processes for professional and instructional leadership; inform pedagogical strategies; response in the context of communication among student individuals and emphasize the human relations to protect the environment.

The formation of students' caring character requires a process. This means that characters can be truly embedded in students through long process and time. Therefore, a habituating effort is a must to be presented in learning so that the actions expressed by students become a character value will arise as the results of the learning process. The endeavour of this habituation must begin from the classroom learning design. Furthermore, the learning process that occurs must be integrated to develop environmental responsible behavior, to build an understanding about the process of natural balance and the role of humans in nature. The all behaviors that are developed certainly require learning that involves students directly. This is aimed to give students the opportunity to learn and train themselves in examining issues related to the environment.

Bottle garden activities are one of the strategies in instilling the character of caring for students' environmental awareness through activities that are built together in improving environmental quality. Students can find out how to conserve plants in a simple and hygiene conscious movement. These efforts are the basis for improving environmental quality. The steps taken in bottle garden activities aimed to help improve the school environment to remain green, the re-utilization of used plastic bottles can reduce trash and waste This also will promote to implement a healthy lifestyle through the use of medicinal plants in the activity of bottle garden, and encourage students to be more active in maintaining the nature. Therefore, not only do the learning through bottle be oriented to the theory or science concepts but also it benefits in learning science process as well as contribute in resulting useful products. The implementation of bottle garden learning has also aroused the spirit of student learning. Participatory-based learning provides opportunities for students to express their respective attitudes to school and society. For students, this environmental-based activities can enrich their knowledge as considerable as strengthen their skills to create and manage learning experiences with others (Sata et al., 2015).

The challenge of embedding the environmental awareness in Christian Junior High School 2 in Salatiga is the lack of integration of environmental awareness in all subjects, especially science subjects. Learning resources and learning media that are environmentally. The efforts in improving the environmental awareness in schools need to be supported in term of improvement and provision of learning resources as well as learning media that are in accordance with the learning patterns and character building. 
(Rahmat, 2009) asserted that the embedded of environmental characteristics and ethics are very important to be done by the school as one of the educational facilities. Therefore, the development of students' character oriented to the environment

can be carried out from simple activities through active learning process (Asmani, 2012; Ridlo \& Irsadi, 2012).

From the findings of this study, the implementation of the environmental awareness of Christian Junior High School 2 in Salatiga and the low comprehension of balance of nature in the students become a concern for educators. These can be applied while the students learn about diversity, ecology, and conservation. It is not merely introducing biology concepts but it is more about training the students to be more aware about their environment. Students can be directed to have the responsibility, as they are the human involved in nature conservation. Therefore, an optimal environmental learning can be provided to support their comprehension and attitude. Thus, students can achieve biology' concept optimally (Ham, Mrčela, \& Horvat, 2016).

\section{CONCLUSION}

The highest achievement of all indicators of environmental awareness was the eco-crisis with a score of 3.43 (good). The lowest score was the natural balance indicator with the $\begin{array}{llll}\text { score } & 3.02 & \text { (moderate). Students' }\end{array}$ understanding of anti-exceptionalism and limit to growth indicators were in adequate level. Students assumed that humans should be in natural law. The bottle garden activity was carried out by linking students' knowledge and applying it in daily life. The attitude of students began to show their concern to the environment and nature preservation when participating in bottle garden making activities through the use of plastic bottles as a planting medium. Students have the opinion that every human activity can affect their surrounding. Creating students who are environmentally aware and participate in protecting their environment is basically forming them to have good moral values. This including the efforts to support the students who like to grow plants and take care them which in turn will educate them to have the discipline, caring, and responsible characters.

\section{REFERENCES}

Aqib, Z. (2011). Pendidikan karakter: Membangun perilaku positif anak bang-sa. Bandung: Yrama Widya.

Asmani, J. (2012). Buku panduan internalisasi pendidikan karakter di sekolah. Yogyakarta: DIVA Press.

Atav, E., Altunoğlu, B. D., \& Sönmez, S. (2015). The determination of the environmental attitudes of secondary education students. Procedia-Social and Behavioral Sciences, 174, 1391-1396. https://doi.org/10.1016/j.sbspro.2015.01. 765

Daniel, E. E., \& Ibok, E. (2013). Solid waste disposal habits of students in Nigerian Universities: A case of University of Uyo, Nigeria. IOSR Journal of Environmental Science, Toxicology and Food Technology (IOSR-JESTFT), 5(6), 46-50. Retrieved from http://www.iosr journals.org/iosr-jestft/papers/vol5-issue6 /I0564650.pdf

Daryanto, \& Darmiatun, S. (2013). Implementasi Pendidikan Karakter di Sekolah. Yogyakarta: Gava Media.

Farida, I., Hadiansah, Mahmud, \& Munandar, A. (2017). Project-based teaching and learning design for internalization of environmental literacy with islamic values. Jurnal Pendidikan IPA Indonesia, 6(2), 277-284. https://doi.org/10.15294/ jpii.v6i2.9452

Grebennikov, V. V, Sangadzhiev, B. V, \& Elena, V. (2016). On the question about the jurisdiction of the courts in cases of crimes against the international environmental safety, 11(18), 1099911006. Retrieved from http://www.ijese. net/makale_indir/1483

Ham, M., Mrčela, D., \& Horvat, M. (2016). Insights for measuring environmental awareness. EKONOMSKI VJESNIK/ ECONVIEWS, 29(1), 159-176. Retrieved from https://hrcak.srce.hr/ojs/index.php/ ekonomski-vjesnik/article/view/3661/24 53

Nazarenko, A. V, \& Kolesnik, A. I. (2018). Raising environmental awareness of future teachers. International Journal of Instruction, 11(3), 63-76. https://doi.org/ 10.12973/iji.2018.1135a

Rahmat, M. (2009). Penanaman etika lingkungan melalui peduli sekolah dan 
berbudaya lingkungan. Jurnal Tabula rasa, 6(2), 8-15. Retrieved from http://digilib.unimed.ac.id/712/1/Penana man etika lingkungan melalui sekolah perduli dan berbudaya lingkungan.pdf

Ramsey, C. E., \& Rickson, R. E. (1976). Attitudes. The Journal of Environmental Education, 8(1), 10-18. https://doi.org /10.1080/00958964.1976.9941552

Ridlo, S., \& Irsadi, A. (2012). Pengembangan nilai karakter konservasi berbasis pembelajaran. Jurnal Penelitian Pendidikan, 29(2), 145-154. https://doi. org/10.15294/jpp.v29i2.5657

Sata, Y., Wongpho, B., \& Chankong, U. (2015). Development of a Learning activity management model with the community learning sources for environmental education. International
Forum of Teaching and Studies, 11(1/2), 13-23.

Setyowati, L. (2015). Integrating character building into teaching to enhance the students environmental awareness. Journal on English as a Foreign Language, 3(1), 1-10. https://doi.org/10. 23971/jefl.v3i1.57

Thomas, G. J. (2018). Pedagogical frameworks in outdoor and environmental education. Journal of Outdoor and Enviromental Education, 21(2018), 173-185. https:// doi.org/10.1007/s42322-018-0014-9

Uno, H. B., \& Nurdin, M. (2011). Belajar dengan pendekatan PAILKEM. Jakarta: PT Bumi Aksara.

Yusuf, S. (2012). Psikologi perkembangan anak dan remaja. Bandung: Remaja Rosda Karya. 